\section{GLOBAL CHANGE}

\section{Sagan appeals to world religious leaders \\ Boston}

Astronomer Carl Sagan and 22 other well-known researchers chose Moscow as the unlikely venue for an appeal to world religious leaders to join scientists in protecting the global environment. The appeal came at a recent conference on the environment and economic development which attracted over a thousand religious, political and scientific leaders from 83 nations.

Ironically, Sagan travelled to the officially atheist Soviet Union to announce "a religious as well as a scientific dimension" to the problems of global change. Even more remarkable, the conference was sponsored by both the USSR Academy of Sciences and the Russian Orthodox Church.

The appeal states that "efforts to safeguard and cherish the environment need to be infused with a vision of the sacred". Among those who have given their backing are physicist Hans Bethe, evolutionary biologist Stephen Jay Gould and former MIT president Jerome Weisner.

The appeal certainly reached a global audience. It, and other parts of the five-day conference, were the first ever to be televised with satellite time provided jointly by the East and West communications networks Intersputnik and Intelsat and reached an estimated audience of 2,000 million people in 129 countries. Later at the conference, more than one hundred religious leaders joined to hail the scientists' appeal as "a unique moment and opportunity in the relationship of science and religion". Seth Shuiman

- Global change 'consensus', page 401.

\section{COMPUTER CRIME}

\section{Cornell hacker is convicted but free \\ Washington}

A PREVIOUSLy untried 1986 law aimed at the prosecution of computer criminals passed muster last week when former Cornell University graduate student Robert Morris Jr was convicted for writing and releasing a "virus" that crashed thousands of computers nationwide in 1988.

Morris has not yet been sentenced, but he is expected to get relatively light punishment. His virus did no permanent damage and his defence attorney described the program as a harmless experiment in testing computer security that went awry. But because Morris' program was clearly written for the purpose of illegally breaking into remote computers and was then released on a national network, federal prosecutors had little difficulty obtaining a conviction.

Cases of a program with less obvious malicious intent or a more modest scope may not be resolved as easily.

G. Christopher Anderson

\title{
US relaxes export curbs
}

Washington \& Munich

IN what administration officials say could be the beginning of a substantial thaw in the restriction of high-technology export to former Soviet-bloc countries, the White House announced last week that it would relax rules on sales to Eastern European nations that have abandoned Communism and are liberalizing their economies.

Although the details of the new policy have not been released, they are believed to include approval of computers six times more powerful than currently allowed, sale of fibre-optic cables and sophisticated machine tools.

The decision comes in response to strong pressure from European allies to rethink export restrictions given the explosive restructuring of Eastern Europe. Since the beginning of the Cold War the US and its allies have withheld technology from Soviet-bloc countries in an attempt to maintain a technological and strategic edge in the West. The Parisbased Coordinating Committee for Multilateral Export Control (CoCom) maintains a list of restricted technologies and monitors sales.

"We now face a situation in which the political and military environment is changing", State Department spokesperson Margaret Tutwiler said in a statement released last week to explain the Administration's shift in position. State Department officials may suggest further liberalizations in June at a major CoCom meeting in Paris, Administration officials said.

Industry sources say that the Administration plans to allow the sale of 32-bit computers, a class that includes the Intel FOSSIL REPTILE
80386 chip that is now common in advanced personal computers. Current CoCom rules allow sale of 16-bit computers of the IBM PC-AT class. The relaxation is also expected to allow scientific equipment based on 32-bit technology. Certain medical diagnostic instruments such as nuclear magnetic resonance spectrometers contain 32-bit microprocessors, as do many other data-processing and analysis devices that are commonly available in the West.

Some European nations reacted sceptically to the US announcement.

In West Germany, officials suggested that the new proposal is more bark than bite. "This is the third or fourth time we've heard that the US wanted to modernize the CoCom list. We've learned to be realistic about these promises", says West German Economics Ministry spokesperson Dede Gaw.

Another source in the ministry says that it seems unrealistic to have different restrictions for the Soviets and other nations - that would force too much responsibility on the other nations to enforce the restrictions. And trying to block out the Soviet Union smacks of Cold War policies, the source says.

Eastern European countries, on the other hand, generally welcomed the US decision, but several said they had not received official word from the administration on what specific changes were planned. US Ambassador Allen Went is expected to make a formal presentation at the June CoCom meeting outlining the specific technologies that would be deregulated.

G. Christopher Anderson \& Steve Dickman

\section{'Lizzie' set to stay at home}

\section{London}

THE earliest-known reptile may end up in Scotland after all, following a surprise announcement from the Museum für Naturkunde in Stuttgart, successful bidders for the $£ 180,000$-specimen (see Nature 343, 106; 11 January 1990). Museum Director Professor Bernhard Ziegler has agreed to delay the purchase of the 338million-year-old fossil, affectionately known as "Lizzie", until after 31 July 1990. This will give the National Museums of Scotland time to match the purchase price.

The 10 -inch fossil was discovered by professional collector Stan Wood at East Kirkton in Lothian, Scotland. His price $£ 207,000$ (including value-added tax), exceeded the budgets of UK museums. But it became clear that the Stuttgart bid was, in part, an attempt to stop the fossil going to a private collection where it would be inaccessible to researchers. Rupert Wild of the Stuttgart Museum admits that Lizzie's proper place is in Edinburgh, with the rest of the East Kirkton collection.

Lizzie will be on display at the Royal Museum of Scotland between 1 March and 27 May: the trustees of the National Museums of Scotland have made available $£ 104,000$ from the 1990-91 purchase grant, and the museums will launch an appeal for the remainder.

Although Lizzie was described in Nature last December (342, 676; 7 December 1989), the author, Timothy Smithson of the University of Newcastle, did not give her a formal zoological name But arrangements can be made to name her after a sponsor.

Henry Geo 